\title{
School Plant Organization, Instructional Efficiency and Students Academic Performance in Osun State Secondary Schools
}

\section{Adedapo Adetiba Atolagbe}

Ph.D, Department of Educational Management, Faculty of Education, University of Ilorin, Ilorin, Nigeria, atolagbe.aa@unilorin.edu.ng

\begin{abstract}
This study observed the effects of school plant organization on instructional efficiency and performance of students in Osun State public secondary schools. It employed a quantitative research design of correlation type. The study sampled 100 public secondary schools in the three senatorial districts of the state using systematic random sampling method. A researcher- designed questionnaire titled "School Plant Organization and Instructional Efficiency Questionnaire" (SPOIEQ) was used to collect data on relative location of school plant facilities in the schools. The construct and content validity of the instrument was done by experts in research. The question items were reviewed by the specialists and corrections were affected as suggested by them. After a test- retest treatment within two weeks interval, the scale recorded a cronbach alpha of 0.75 . The study found out that most specialized school plant facilities (laboratories, libraries, playgrounds, workshops, hostels and staff offices) were located considerable distance from the classrooms thus requiring longer mean time for teachers and students to move into or from them for teaching and learning. Also, a significant relationship was established between school plant, instructional efficiency and academic performance with F- value $(0.36)>$ critical Fvalue (0.19) at. o5 level of significance. School plant organization and student attendance/ punctuality at lessons were found to be significantly related with F-value $(0.7921)>$ critical Fvalue (0.16) at .05 level of significance. School plant organization and teachers attendance/ lesson completion was found to be significantly related with F-value $(0.5500)>$ critical F-value (0.16) at .05 level of significance. The study concluded that school plant location have a role to play on the effectiveness of instruction and the ultimate performance of students in their examinations. It thus recommended the construction of 'Integrated Classrooms' that can house almost all teaching activities under one big roof.
\end{abstract}

Keywords: school plant, instructional efficiency, specialized school rooms, integrated classroom

\section{INTRODUCTION}

One of the objectives of educational institutions in Nigeria is to produce the required manpower for all sectors of the economy. In order to actualize this objective, school plant plays an important role in our educational system. Adeboyeje (2000) describes school plants as the school site, buildings, classrooms, corridors, playgrounds, sanitary facilities, furniture and other equipment minus the consumable materials. It is the space interpretation of the school curriculum, the ways in which curriculum finds its physical expression. The school administrator should consider not the staff and students alone but the suitability of the site, situation, organization and location of the school itself. The appropriate location of the classrooms, laboratories, conveniences, playground etc; in relation to one another and with consideration for easy access and co-ordination of all school activities should be the concern of all school administrators. School plant organization involves the arrangement and location of classroom blocks, organization of school, hostel blocks, kitchen and dining hall, science

Citation: Atolagbe, A. A. (2019). U School Plant Organization, Instructional Efficiency and Students Academic Performance in Osun State Secondary Schools. Anatolian Journal of Education, 4(1), 13-22. https://doi.org/10.29333/aje.2019.412a 
laboratories and agricultural science block, technology workshop, arts and typing rooms assembly hall, students' common room, staff offices with administrative and teachers office, water supply, power supply, adequate supply of furniture and equipment to include seats and desks, laboratory equipment and audio-visual aids and as well as books on every subjects and toilets(Oladejo,2004). School plant is an integral part of the learning environment which constitute major determinant towards ensuring quality educational system. The planning, organization, and location could be a decisive factor in achieving the goals of education. School plant is considered as the most prominent indicator of shelter that protect school administrators, teachers, students from rain, sun, hot/cold weather and destruction, it represents the location of school environment, educational facilities, organizing blocks and equipment in the proper position which has a tremendous positive impact on the comfort, safety and academic performance of the students.

Theodore (2010) carried out a study on managing school facilities and students' academic performance in which facilities organization is embedded, he was of the view that availability of facilities is one thing and another thing is their arrangement to suit the purpose for which they are designed. Theodore (2010) found school facilities organization as having impact on the academic performance of students, either positively or otherwise. According to him, school building organization accounted for 3.7 percent to 6.3 percent of the variance on 5 of the 9 subjects of the learning when facilities arrangement is correlated with the composite score of the students in lower test of basic skills. In other words, these percentages represent how many the facilities arrangement accounted for the difference between the score of students in modern and traditional schools. Owoeye (2011) found that a difference between the mean test scores of students in traditional and modern school facilities arrangement to be 2.55 point from reaching 7.67 point for mathematics. All things being equal, students in modern schools perform better on achievement test than students in traditional schools. He developed an instrument to measure the arrangement of school facilities. The instrument had components of school facilities with measurable influence upon students' academic performance. He found that performance scores of students in sub- standard school facilities to be from 3 to 7 percent points below the scores of students in above standard school facilities.

Akinsolu (2004) was of the opinion that, educational curriculum cannot be sound and well with poor and badly organized school facilities. Provision of safe and adequate facilities with balanced visual environment and sufficient shelter space for work and play ensures emotional needs of students are met and could create an inspiring learning environment. Conducive school physical environment could enhance students' school enrolment, school attendance and involvement in academic activities which could boost academic performance positively. Adeboyeje (2000) observed that, schools with wellcoordinated plant planning and maintenance practices recorded better student performance. The realization of an effective teaching and learning is not unconnected with location of the school, the organisation and arrangement of the physical structures and other educational facilities in the school (Muraina, Ijaduola \& Oni,2011). 
Conceptual framework

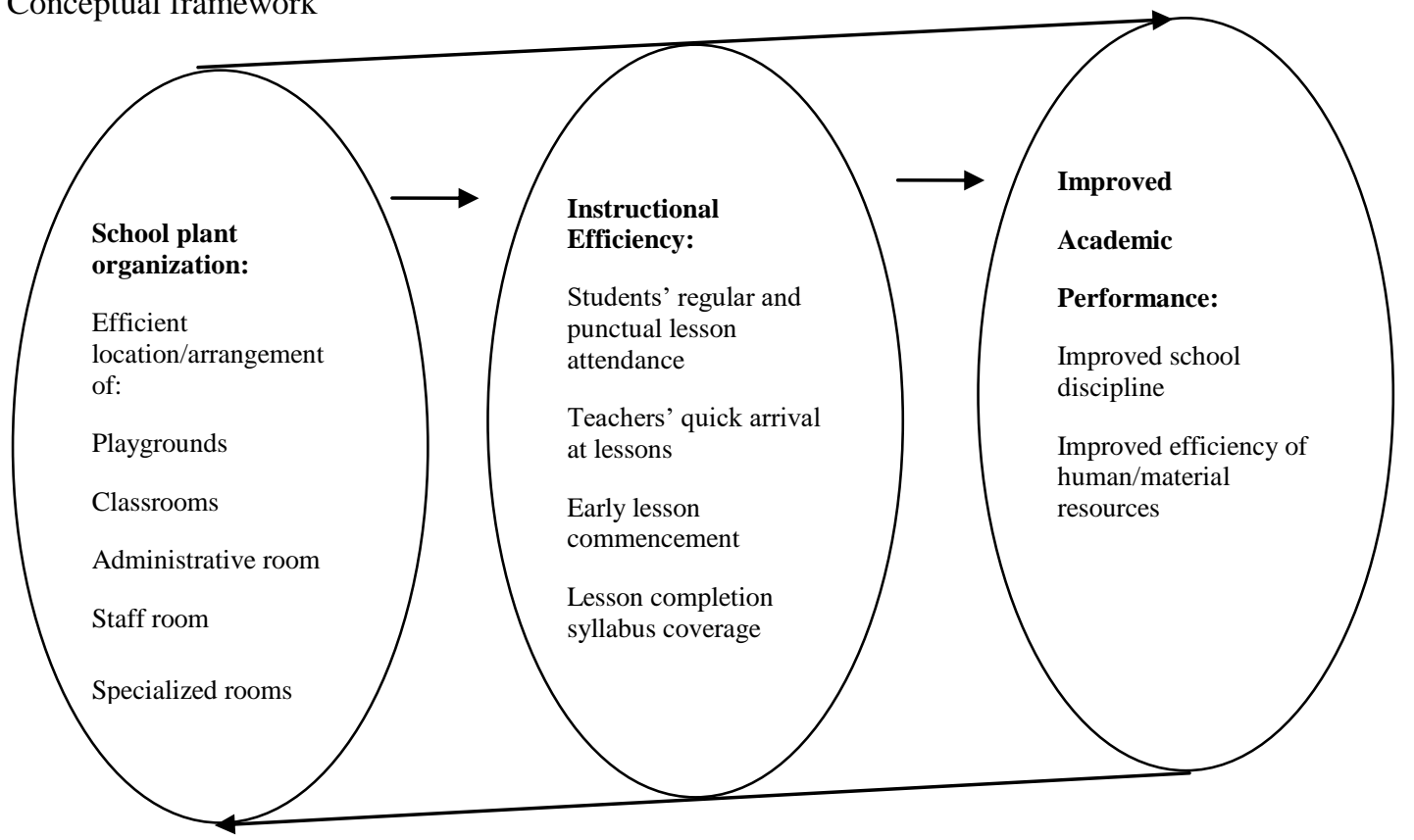

Figure 1

Model of Relationship Among School Plant Organization, Instructional Efficiency and Academic Performance

The model depicts the interactive nature of the variables in the study. School plant organization is the independent variable that is concerned with spatial location/arrangement of school plant in a way that lesson time could be effectively used by reducing distance between teachers' offices and classrooms as well as distance between specialized rooms such as laboratories, workshops and library and classrooms. This will enable teachers to get to their various lesson rooms early enough for lesson commencement. Not only teachers, student's time taken to change from one specialized teaching room to the normal classrooms after lesson completion will be shortened and incidence of lateness/ absence from lessons will reduce.

The instructional efficiency is an intervening variable which could be affected by school plant organization and itself exerts a lot of influence of students' academic performance. When school plants are effectively located and arranged, lesson delivery by teachers will be very effective and efficient because teachers and students lesson attendance will be very high, high punctuality rate will assure lesson completion within the allotted time frame.

\section{METHOD}

The research design adopted for this study was quantitative research of correlation type. This design was considered appropriate taking into consideration the focus of the study. The study sample consisted of 100 out of the 315 public secondary schools in the state. Multi- stage sampling technique was used, the schools were stratified into three Senatorial Zone. Schools within each zone were selected proportionally using systematic random sampling technique. Data were obtained through the use of a 20-items, four points Likert-type questionnaires named School Plant Organization and Instructional Efficiency Questionnaire (SPOIEQ). The corresponding scores for rating the responses were: Strongly Agree (SA) 4points, agree(A) 3 points, Disagree (D) 2 points, Strongly Disagree (SA) 
1 point. The construct and content validity of the instrument was done by experts in research. The question items were reviewed by the specialists and corrections were affected as suggested by them. After a test- retest treatment within two weeks interval, the scale recorded a cronbach alpha of 0.75 . A checklist titled "Students' Academic Performance Checklist" (SAPC) which was used to collect information on the performance of students in Senior Secondary Certificate Examination (SSCE) conducted by the West African Examination Council (WAEC) between 2013 and 2016. Performances were rated on four points Likert scale type. Results with 5 credits (including English and Mathematics) and above were rated Very Good (VG);4 points 5 credits with English and Mathematics (Good) 3 points, those with 5 passes including English and Mathematics were rated Average (AV) 2 points, and performance below 5 passes were rated Poor $(\mathrm{P})$ 1point. The data collected were analysed using multiple regression analysis where the construct of the two variables were regressed against academic performance.

\section{Statement of the Problem}

The organization of the school building and facilities raised serious concerns and go a long way in determining students' academic performance. The school programmers (curricular and co-curricular) are time mindful and specific. The average time for students to cover curriculum of studies and for them to attempt various evaluation and performance tests by examining bodies is also not variable. There is thus the need to maximize school time effectively and efficiently by reducing time wastage to its barest minimum. Much of students and staff time in school is wasted in between lesson periods as well as in between different break times and the commencement of the next lessons.

Most literature on school plant spent a lot of efforts connecting school plant provision with academic performance; Owoeye(2008, Emetaron,2004), while many others harps on importance of school plant utilization in enhancing student achievement; Ashioya(2012), Akinsanya(2010). Some other scholars were concerned with school facilities maintenance as it affects student learning outcomes. Works of Akinsolu(2004) and Adeboyeje(2000) shows that school facilities maintenance were the most potent determinant of academic achievement. However, where school facilities were provided and utilized and regularly maintained, and students learning outcomes are still below expectations, research efforts must be geared towards other aspects of school facilities that have not been fully explored and could significantly influence schools, teachers and students teaching and learning efforts. Amanckwu and Olulube (2015) observed a close relationship between school physical environment and academic performance of students, they were of the opinion that the education received by children bears direct relevance to the availability or lack, thereof of physical facilities and the overall atmosphere in which learning takes place.

Where school plants are disproportionately oriented and connected, much needed time is consumed when teachers and students moved from one lesson period to another especially lesson that requires students leaving their classes to take lessons in specialized rooms (laboratories, workshops, art studio, gymnasium and playing grounds) same is the experience of teachers who take different classes and have to switch lessons between various arms of the school. With classes and staff common room located distances away from each other, teachers do experience lateness to their classes and lessons may commence late leading to inefficiencies in the delivery of instruction. The study is concerned with the problems of instructional efficiency due to inappropriate organization of school plants which often time lead to poor lesson delivery, poor student and teacher attendance at lessons, non-completion of lessons due to lateness and inadequate time for lesson evaluation. All of these may attribute to poor student learning and understanding and the result will most times manifest in poor student achievement.

It is in this regard that the researcher examined the relationship between school plant organization and students' academic performance in Senior Secondary Schools in Osun State 


\section{Purpose of the Study}

The study investigated the relationship among school plant organization, instructional efficiency and students' academic performance in Osun State Senior Secondary Schools. Specifically, the study sought to;

i. examine the influence of classroom, laboratory and school playgrounds organization has on student academic performances

ii. investigate whether organization of school plant has influence on students' punctuality and attendance of lessons.

iii. determine the extent to which organization of school plants affects teachers' lesson commencement time and completion rates, and

iv. determine which of the variables has the greatest influence of students' academic performance.

\section{Research Question}

What are the combined effects of school plants organization and instructional efficiency on students' academic performance in Osun State Public Secondary Schools?

\section{Research Hypotheses}

$\mathrm{Ho}_{1}$ : There is no significant relationship among school plant organization, instructional efficiency and Students' Academic Performance in Osun State Senior Secondary Schools.

$\mathrm{Ho}_{2}$ : There is no significant relationship between school plant organization and student attendance/ punctuality at lessons in Osun State Senior Secondary Schools

$\mathrm{Ho}_{3}$ : There is no significant relationship between school plant organization and teachers lesson attendance/completion time in Osun State Senior Secondary Schools.

\section{FINDINGS}

Research Question: What are the contributions of school plant organization and instructional efficiency variables on Students' Academic Performance?

Table 1

Contributions of School Plant and Instructional Efficiency Variables on Students' Academic Performance Coefficients

\begin{tabular}{clllll}
\hline Variables & \multicolumn{1}{c}{ Beta } & Standard error & t cal & t tab & Remark \\
\hline $\mathrm{X}_{1}$ & 0.7701 & 0.1307 & 5.8921 & 1.65 & $\mathrm{X}_{1 \text { is }}$ significant \\
$\mathrm{X}_{2}$ & 0,05600 & 0.0378 & 14.8148 & 1.65 & $\mathrm{X}_{2}$ is significant \\
$\mathrm{X}_{3}$ & 30.6100 & 0.0132 & 46.2121 & 1.65 & $\mathrm{X}_{3}$ is significant \\
$\mathrm{X}_{4}$ & 0.7501 & 0.2039 & 3.6787 & 1.65 & $\mathrm{X}_{4}$ is significant \\
$\mathrm{X}_{5}$ & 0.6392 & 0.03414 & 20.3566 & 1.65 & $\mathrm{X}_{5 \text { is significant }}$ \\
Constant & 7.668113 & 5.5717 & & & \\
\hline
\end{tabular}

Table 1 shows the relative contributions of variables $\mathrm{X}_{1}, \mathrm{X}_{2}, \mathrm{X}_{3}, \mathrm{X}_{4}$ and $\mathrm{X}_{5}$ on the dependent variable academic performance. The regression equation is

$\mathrm{Y}^{1}=\mathrm{a}+\mathrm{b}_{1} \mathrm{X}_{1}+\mathrm{b}_{2} \mathrm{X}_{2}+\mathrm{b}_{3} \mathrm{X}_{3}+\mathrm{b}_{4} \mathrm{X}_{4}+\mathrm{b}_{5} \mathrm{X}_{5}+\mathrm{e}$

Where:

$\mathrm{X}_{1}$ means school plant organization

$\mathrm{X}_{2}$ means instructional efficiency

$\mathrm{X}_{3}$ means specialized rooms location

$\mathrm{X}_{4}$ means playgrounds location 
$\mathrm{X}_{5}$ means lesson attendance/ completion time

a means constant;

$\beta$ means beta and

e means standard error.

Substituting the values of constant (a), beta $(\beta)$ and standard error (e) from the table in the regression equation gives:

$\mathrm{Y}^{1}=7.668113+0.7701 \mathrm{X}_{1}+0.5600 \mathrm{X}_{2}+0.6100 \mathrm{X}_{3}+0.7501 \mathrm{X}_{4}+0.6392 \mathrm{X}_{5}+57171$

That is for every point increase in the prediction variables $\left(\mathrm{X}_{1}, \mathrm{X}_{2}, \mathrm{X}_{3}, \mathrm{X}_{4}\right.$ and $\left.\mathrm{X}_{5}\right)$, there will be a corresponding increase of $77.01 \%, 56.6 \%, 61.0 \%, 75.01 \%$ and $63.9 \%$ in the predicted variables $\left(\mathrm{Y}^{1}\right)$ respectively.

The significant test of variables $\left(\mathrm{X}_{1}, \mathrm{X}_{2}, \mathrm{X}_{3}, \mathrm{X}_{4}\right.$ and $\left.\mathrm{X}_{5}\right)$ shows that they all have a significant impact on academic performance because the calculated $\mathrm{t}(5.8921$ is greater than table $\mathrm{t}(1.65)$ for school plant organization and calculated $\mathrm{t}(14.8148)$, is greater than table $\mathrm{t}(1.65)$ for instructional efficiency. Also calculated $\mathrm{t}(46.2121)$ is greater than table $\mathrm{t}(1.65)$ for location of specialized instructional rooms while calculated $t$ (3.6787) is greater than table $t(1.65)$ for playgrounds location and calculated $\mathrm{t}(20.3566)$ is greater than table $\mathrm{t}(1.65)$ for lesson attendances and completion time respectively.

The implication of this is that if specialized instructional rooms like laboratories and workshops are organized and located close to normal classrooms where students conventionally resides, the time required by students to get to these rooms for lessons will reduce considerably making attendance and punctuality at lessons very easy this will in turn help teachers complete planned instructional contents promptly and have time for evaluation and feedbacks. Also, in situation where school playgrounds were located at considerable distance way from classrooms and administrative offices, the tendency for students to overstay on the field and playgrounds is very high with many missing lessons that follow breaks and activities observed on school recreation grounds. Therefore, school plants must be located in a close knitted way that will reduce time required to move from one specialized instructional room to the other and as well make it easier for teachers on duty to closely monitor compliance with school rules and regulations concerning observation of break times and return to normal lessons after playground activates.

\section{Hypotheses Testing}

The research hypothesis states that, "there is no significant relationship among school plant organization, instructional efficiency and students' academic performance in Osun State public secondary schools" the hypothesis was tested using multiple regression statistical analysis the results are shown below

Table 2

Matrix Coefficient of Relationship Among School Plant Organization, Instructional Efficiency and Academic Performance In Osun State Public Secondary Schools

$\mathrm{X}_{1} \quad 1.000$

$\mathrm{X}_{2} \quad 0.4312 \quad 1.000$

$\begin{array}{llll}\mathrm{X}_{3} & 0.3480 & 0.5160 & 1.000\end{array}$

$\begin{array}{lllll}\mathrm{X}_{4} & 0.6851 & 0.4872 & 0.5521 & 1.000\end{array}$

$\begin{array}{llllll}\mathrm{X}_{5} & 0.5693 & 0.3211 & 0.3927 & 0.2891 & 1.000\end{array}$

$\begin{array}{lllllll}\mathrm{Y}^{1} & 0.8261 & 0.7558 & 0.5811 & 0.3837 & 0.4381 & 1.000\end{array}$

Where:

$\mathrm{X}_{1}$ means school plant organization 
$\mathrm{X}_{2}$ means instructional efficiency

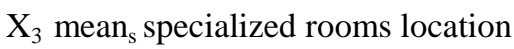

$\mathrm{X}_{4}$ means playgrounds location

$\mathrm{X}_{5}$ means lesson attendance/ completion time

$\mathrm{Y}^{1}$ means academic performance

Table 2 shows the zero-order correlation coefficient matrix of the relationship among all the components of the independent variables and the dependent variable. School plant organization $\left(\mathrm{X}_{1}\right)$ had the highest correlation of (.8261) with academic performance $\left(\mathrm{Y}^{1}\right)$, while instructional efficiency ranked second (.7558). Specialized instructional rooms ranked third (.5811), play grounds location ranked fourth (.4381), and lesson completion by teachers ranked fifth (.3839). Both $\mathrm{X}_{4}$ and $\mathrm{X}_{5}$ have low but positive correlation with academic performance. The result indicates that school plant organization and instructional efficiency had strong and positive relationship with academic performance with $r=.8261$ and $r=.7558$ respectively. Furthermore, specialized instructional rooms had moderate positive relationship with academic performance with $r=.5811$, while location of play grounds and lesson attendance and completion rate premised on school plant organization had weak positive relationship with academic performance with $\mathrm{r}=.3837$ and $\mathrm{r}=.4381$ respectively

Table 3

Relationship Among School Plant Organization, Instructional Efficiency and Students' Academic Performance in Osun State Public Secondary Schools

\begin{tabular}{lcccccc}
\hline Source & Df & $\begin{array}{c}\text { Sum of } \\
\text { square }\end{array}$ & $\begin{array}{c}\text { Mean of } \\
\text { square }\end{array}$ & $\begin{array}{c}\text { Calculated } \\
\text { F-value }\end{array}$ & $\begin{array}{c}\text { Table } \\
\text { F-value }\end{array}$ & Decision \\
\hline Regression & 2 & 75191.67 & 37595.84 & 0.36 & 0.19 & $\begin{array}{c}\mathrm{H}_{\mathrm{O}} \\
\text { Rejected }\end{array}$ \\
Residual & 100 & 692517.7 & 6925.18 & & & \\
\hline $\mathrm{R}^{2}=0.4692$ & & & & & &
\end{tabular}

The calculated F- value $(0.36)$ is greater than the critical F- value $(0.19)$ at .05 level of significance. The hypothesis is therefore rejected. This implies that, there is a significant relationship among school plant organization, instructional efficiency and student academic performance.

The $\mathrm{R}^{2}$ of 0.4692 measures the variability in the dependent variable that can be explained by the influences of the two-independent variable $\mathrm{X}_{1}$ and $\mathrm{X}_{2}$. The $\mathrm{R}^{2}$ of 0.4692 means that $46.9 \%$ of the variability of academic performance can be explained by the combine influence of school plant organization and instructional efficiency. Since $46.9 \%$ is moderately high, then the influences of the two independent variables on academic performance are significant

Table 4

Relationship Between School Plant Organization, and Students' Attendance/ Punctuality at Lessons in Osun State Public Secondary Schools

\begin{tabular}{lcccccc}
\hline Source & Df & $\begin{array}{c}\text { Sum of } \\
\text { square }\end{array}$ & $\begin{array}{c}\text { Mean of } \\
\text { square }\end{array}$ & $\begin{array}{c}\text { Calculated } \\
\text { F-value }\end{array}$ & $\begin{array}{c}\text { Table } \\
\text { F-value }\end{array}$ & Decision \\
\hline Regression & 1 & 35.07467 & 35.07467 & & & $\begin{array}{c}\mathrm{H}_{\mathrm{O}} \\
\text { Rejected }\end{array}$ \\
Residual & 100 & 4457.12217 & 44.57 & 0.7921 & 0.16 & \\
\hline
\end{tabular}

$\mathrm{R}^{2}=0.5926$

The result of the significant test between school plant organization and student attendance and punctuality in the class as shown by table 4 indicates a positive significant relationship between the 
two variables. The calculated F-value $(0.7921)$ is greater than the critical F- value $(0.16)$ at .05 level of significance.

The $\mathrm{R}^{2}$ of 0.5926 shows that $59 \%$ of the variability in instructional efficiency can be explained by the influence of student attendance and punctuality at lessons.

Table 5

Relationship Between School Plant Organization, and Teachers' Attendance/ Lesson Completion Rate in Osun State Public Secondary Schools

\begin{tabular}{|c|c|c|c|c|c|c|}
\hline Source & Df & $\begin{array}{l}\text { Sum of } \\
\text { square }\end{array}$ & $\begin{array}{l}\text { Mean of } \\
\text { square }\end{array}$ & $\begin{array}{l}\text { Calculated } \\
\text { F-value }\end{array}$ & $\begin{array}{c}\text { Table } \\
\text { F-value }\end{array}$ & Decision \\
\hline Regression & 1 & 34.734 & 34.734 & & & $\mathrm{H}_{\mathrm{O}}$ \\
\hline Residual & 100 & 6302.34083 & 63.0211 & 0.5500 & 0.16 & Rejected \\
\hline
\end{tabular}

$\mathrm{R}^{2}=0.7427$

Table 5 shows the result of regression analysis testing the relationship between school plant organization and teachers' attendance/ lesson completion rates in Osun state public secondary schools. The calculated F-value $(0,5500)$ is greater than the critical F-value $(0.16)$ at .05 level of significance. The null hypothesis is therefore rejected.

The $\mathrm{R}^{2}$ of 0.7427 shows that the variability in instructional efficiency can be explained with $74,2 \%$ of the influence of teachers' punctuality at lessons and lesson completion rates by teachers. Since $74.2 \%$ is high, hence the model is adequate enough.

\section{CONCLUSION, DISCUSSION AND SUGGESTIONS}

From the answer to the research question and results from analysis of the hypotheses one can conclude that;

1. There is a significant contribution of school plant organization on instructional efficiency which also significantly influence the academic performance of students in Osun State secondary schools.

2. There is a positive coefficient of relationship among all the variables. Location of playgrounds and specialized rooms had high positive relationship with academic performance while lesson attendance and completion time had the highest positive coefficient with performance.

3. From the hypotheses testing there is a significant relationship among school plant organization, instructional efficiency and academic performance.

4. There is a significant relationship between school plant organization and student lesson attendance and punctuality

5. There is a significant relationship between school plant organization and teachers' lesson attendance and completion time.

\section{Discussion}

The first hypothesis tested postulated that there is no significant relationship among school plant organisation, instructional efficiency and students' academic performance. The analysis showed established a significant relationship among the variables. This finding aligns with Muraina,etal(2011) which revealed that realization of school goals and objectives is connected with location of school, the organisation and arrangement of the physical structures and other educational facilities. A wellarranged and structured school plant will enhance increased academic performance of the students, since efficiency and effectiveness of school time may be guaranteed and enhanced by both students and teachers. The second hypothesis established a significant relationship between school plant organisation and student attendance and punctuality at lessons. This aligns with the submission of 
Gottfried (2010) that there is a statistically significant relationship between student attendance and academic achievement of both elementary and middle school students in Philadelphia school district. When school buildings are arranged a located in the premises in a way that academic time and space are maximized by guaranteeing prompt access and location of school plants by both teachers and students' delivery of instruction will be fast and regular. The third hypothesis established a significant relationship between school plant organization and teachers lesson attendance/completion time. This is in agreement with the findings of Sahito, Khawaja, Panhwar, Siddiqui and Saeed (2016) that found a significant relationship between teachers' time management and students' academic performance through such activities as regularity and punctuality; advanced preparation of different schedules, and lesson plans preparation. Prompt and efficient instructional delivery may lead to curriculum content coverage and allows for regular evaluation of student achievement and provide for revision of noticeable deficiencies before students sits for their examinations. Managing school instructional time has always been a challenge to school administrators. When school plants are closely located reducing access time teachers may be prompt in attending lessons. Students will also save a lot of time when returning to their classes from the parks, gardens, sports arena and hostels after observing different breaks. Time saved as a result of effective school plant organization will engender teachers and students' punctuality in class which may have positive influence on their performance.

\section{Recommendations}

Based on these findings the study is making the following recommendations are advanced towards improving students' performance through effective and efficient school plant organization.

1. Adequate effort should be made to re-design most public schools in the state in a way that all school teaching/learning activities could be centralized/housed within a school building as currently been done in "Osun Millennium Schools".

2. School recreations/playgrounds should also be re-designed in a way that all sporting activities are centralized. It will be easier for teachers and students' officers on duty to promptly direct students to their classes after break periods or at the end of school activities that have to be done on the playgrounds.

3. Specialized school buildings, rooms and workshops location should also take into consideration, distances and time required for teachers and students to shift from them to regular classes or viceversa.

4. Administrative offices, staff rooms and counseling room should be located within minimum trekking distance between students' classes for prompt lesson attendance and attention of teachers on issues/situations where their prompt intervention may be required.

\section{REFERENCES}

Adeboyeje, R. A. (2000). A practical approach to effective utilization and maintenance of physical facilities in secondary schools. Ondo: Clavarianum Press.

Adeogun, A. A. (2001). School plant planning and facilities management. Lagos: Frank Unity Publishers.

Akinsanya, O. (2010). Differential distribution and utilization of human and matrrial resources on student academic performance in secondary schools in Ogun State. African Journal for the study of Educational Issues, 3(4), 40-57.

Akinsolu, R. A. (2004). Provision and management of facilities in Nigerian primary schools. In E. O. Fagbamiye, J. B. Babalola, M. Fabunmi and Ayeni (Eds.), Management of primary and secondary education in Nigeria. NAEAP Publications. 
Amanckwu, R. N., \& Ololude, N. P. (2015). Managing school plant for effective service delivery in public secondary school in River State of Nigeria. Human Resource Management Research, 5(4), 95105

Ashioya, B. M. (2012). Factors affecting utilization of secondary school libraries in Vihiga district, western province of Kenya. (Doctoral dissertation). Kenyata University, Kenya.

Bello, K. Y. (2010). School plant planning, depreciation and students' academic performance in Senior Secondary Schools in Kwara state of Nigeria. (Masters thesis) University of Ilorin, Ilorin.

Emetaron, U. C. (2004). Provision and management of facilities in primary schools in Nigeria: Implication for policy formulation. www.afrrevjo.net 202 Indexed African Journal Online:www.ajol.info.

Gottfried, M. A. (2010). Evaluating the relationship between student attendance and achievement in urban elementary and middle schools. An instrumental approach. American Educational Research Journal. https;//doi.org/10.3102/0002831209350494

Muraina, K. O., Ijaduola, K., \& Oni, J. (2011). Empirical analysis of school plant as a determinant of secondary school students' academic performance. Academic Leadership: The Online Journal, 9(1) https://schools.fhsu.edu/a/j/vol9/iss//22

Sahito, Z., Khawaja, M., Panhwar, U. M., Siddiqui, A., \& Saeed, H. (2016). Teachers' time management and performance of students; A comparison of government and private schools of Hyderabad, Sindh, Pakistan. World Journal of Education,6(6),42-50 http://wje.sciedupress.com

Ogunsaju, A. O. (2004). A guide to school effectiveness in Nigeria. Ibadan: Laville Publications.

Olagunju, A. M., \& Abiola, O. F. (2008). Production and utilization of resources in Biology Education: A case study of south west Nigerian secondary schools. International Journal of Africa and African-American Studies, 11(2), 20-38.

Oladejo, M. A. (2004). The use of modern management and planning technique for greater organizational efficiency in management for quality education. Oyo; Tobistic Printing Press.

Owoeye, J. S. (2011). School facilities and academic achievement of secondary school Agricultural Science in Ekiti State, Nigeria Foundation.

Theodore, J. K. (2010). Planning and managing school facilities. Greenwood Publishers.

Uko, E. S. (2015). Principal ship and effective management of facilities in secondary schools in Cross River State,Nigeria. International Journal of Academic Research and Reflection,3(1), 64-76

United Nations Educational, Scientific, and Cultural Organization. (2008). Historical context of school buildings and facilities program. Retrieved from shttp:www.unesco.org/Education/education/educprog/erd/English/ear/text/ prog1.html 